\title{
Дослідження характеристик холодильної машини, працюючої на на- туральних альтернативних холодоагентах
}

\author{
I. О. Подмазко, О. С. Подмазко \\ Одеська національна академія харчових технологій, вул. Канатна,112, м. Одеса, 65039, Україна
}

\begin{abstract}
Проведено теоретичне дослідження характеристик одноступеневої холодильної машини на сучасних холодоагентах, щзо застосовуються в холодильній техніці, а також, у якості альтернативного варіанту - на природних холодоагентах, зокрема аміак, пропан, пропілен, бутан та ізобутан. На основі проведеного теоретичного дослідження представлена порівняльна графоаналітична залежність основних показників холодильної машини - коефіиієнта подачі компресора, теоретичного об 'єму компресора, споживаної електродвигуном компресора потужності та холодильного коефіцієнта - від температури кипіння холодильного агенту при різних температурах конденсаціï.
\end{abstract}

Ключові слова: Холодильна машина; ОDP; GWP; Холодоагент

(C) The Author(s) 2018. This article is an open access publication

This work is licensed under the Creative Commons Attribution 4.0 International License (CC BY) http://creativecommons.org/licenses/by/4.0/

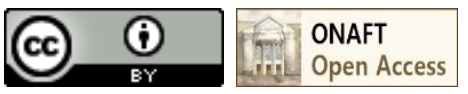

\section{1. Вступ}

У міру подолання проблеми озонової кризи кінця минулого століття на даний момент саме глобальне потепління атмосфери Землі виходить на перший план і стає головною екологічною проблемою XXI століття [1 - 4]. У зв'язку з цим виник істотний тиск на холодильну i компресорну техніку з метою значного скорочення викидів в довкілля парникових газів. Особливо це стосується різних гідрофторвуглеців (HFCs). Внаслідок цього інтерес фахівців і вчених все більше почала притягати можливість повсюдного застосування в холодильній і компресорній техніці природних речовин, які практично не спричиняють вплив на парниковий ефект атмосфери. Серед цих речовин можна виділити аміак, вуглеводні, діоксид вуглецю і деякі інші.

Розвиток холодильної техніки в теперішній час перебуває під впливом трьох визначуваних екологічними проблемами взаємозв'язаних чинників:

- вимог Монреальського протоколу про припинення споживання речовин, що руйнують озоновий шар (в першу чергу широко поширеного холодоагенту R12) i про тимчасове і кількісне обмеження застосування речовин перехідної групи, мають малий потенціал руйнування озонового шару (ODP) (рисунок 1);

- вимог Кіотського протоколу до «Рамкової конвенції ООН про змінення клімату» про регулювання емісії парникових газів (речовин, що мають високий потенціал глобального потепління - GWP), до яких відносяться широко вживаний холодоагент R134a i багато інших речовин, використовуваних в холодильній техніці (рисунок 2);

- традиційної вимоги до підвищення енергоефективності усіх видів холодильної техніки, що обумовлено зростаючою конкуренцією на вітчизняному ринку i положеннями певних законів «Про енергоефективність» і вимогами стандартів про обов'язкове виявлення та інформування споживачів про клас енергоефективності холодильних установок.

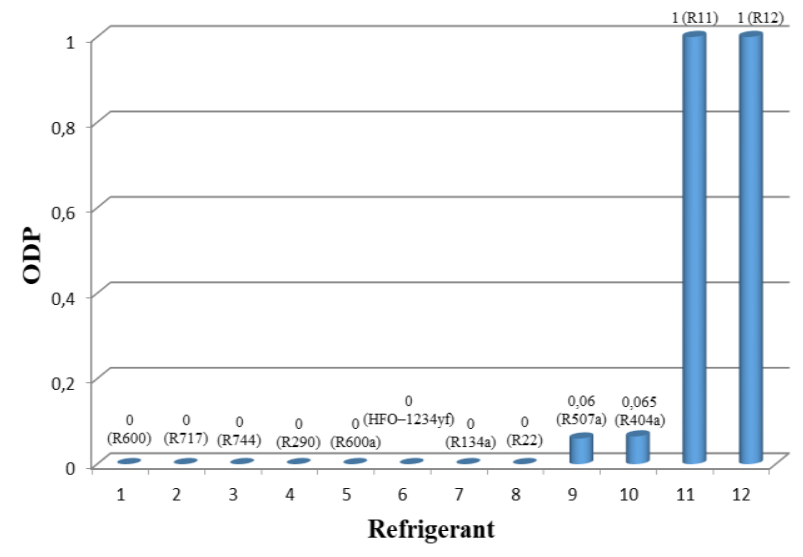

Рисунок 1 - Потенціал руйнування озонового шару (ODP) для найбільш поширених холодильних агентів

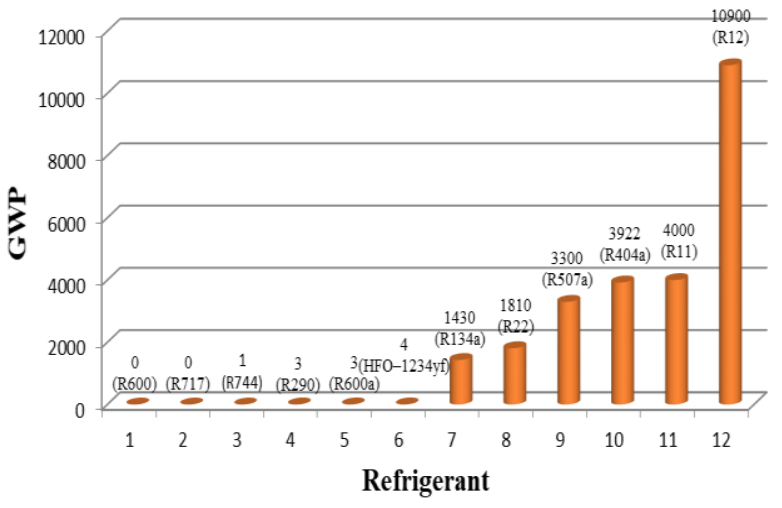

Рисунок 2 - Потенціал парникового ефекту (GWP) для найбільш поширених холодильних агентів 


\section{2. Порівняльний аналіз характеристик холоди- льної машини на різних робочих речовинах}

Метою дослідження $\epsilon$ порівняння та зіставлення характеристик холодильної машини, в якій в якості робочої речовини виступають холодоагенти груп НСFC i $\mathrm{HFC}$, які на даний момент повсюдно застосовуються в холодильній промисловості, та альтернативні натуральні холодоагенті, які ще не здобули широкого поширення, але через Кіотський та Монреальський протоколи $є$ суттєвою альтернативою існуючим холодоагентам груп НCFC і HFC.

Було проведене теоретичне дослідження одноступеневої холодильної машини на 15 -ти робочих речовинах (R717，R600，R600a，R290，R1270，R134a， R142b, R22，R32，R404a，R407c，R410a，R507a，R401a，R502). Схема холодильної машини та ії цикл в діаграмі $\operatorname{lgP}-\mathrm{h}$ приведені на рисунку 3. Винятком було теоретичне дослідження холодильної машини 3 аміаком в якості робочої речовини. Схема цієї машини відрізняється відсутністю РТО. Цикл діаграми одноступеневої аміачної холодильної машини приведений на рисунку 4.
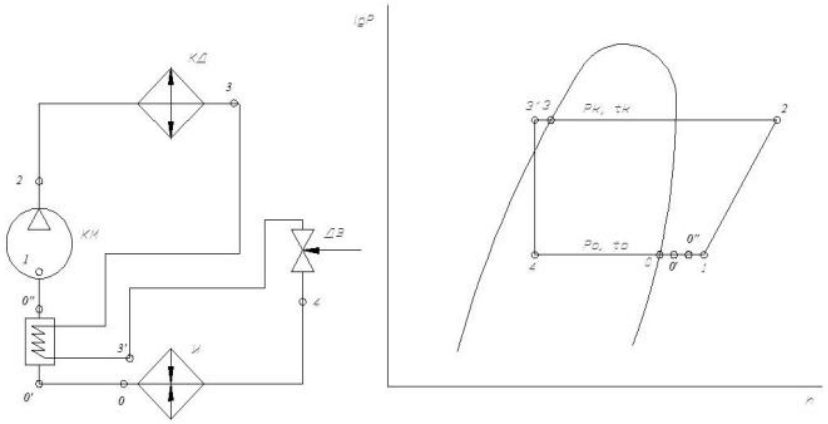

Рисунок 3 - Схема одноступеневої холодильної машини з РТО та ї̈ иикл в діаграмі $\lg P-h$

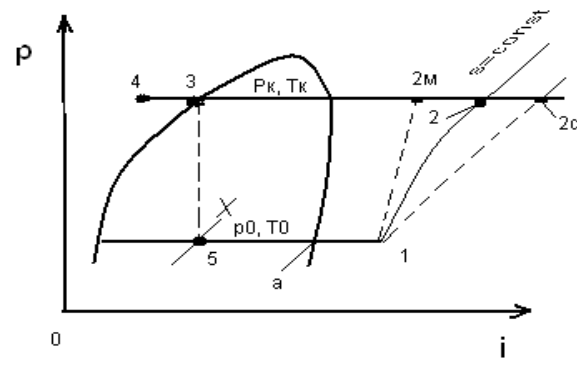

Рисунок 4 - Цикл аміачної одноступеневої холодильної машини в діаграмі $\lg P-h$

Вхідні дані:

- холодопродуктивність $Q_{0}=10$ кВт;

- температури кипіння $t_{0}=-45 \ldots-5{ }^{\circ} \mathrm{C}$;

- температури конденсації $t_{K}=25 \ldots 45^{\circ} \mathrm{C}$;

- перегрівання пари холодоагенту у випарнику

$\Delta t_{B}=3{ }^{\circ} \mathrm{C}$

- перегрівання пари холодоагенту у РТО

$\Delta t_{P T O}=10^{\circ} \mathrm{C}$

- перегрівання пари холодоагенту у всмоктувальному трубопроводі перед компресором $\Delta t_{B C M . T P .}=5{ }^{\circ} \mathrm{C}$;

- переохолодження рідкого холодоагенту у конденсаторі $\Delta t_{\text {MEP.K }}=4{ }^{\circ} \mathrm{C}$.

Деякі $з$ результатів розрахунків представлені на рисунках $5-25$.

Позначення холодоагентів на рисунках:

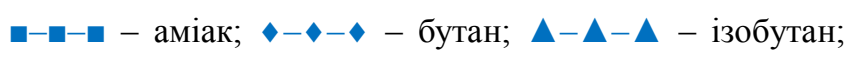

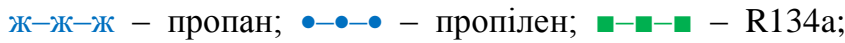
$\checkmark--\mathrm{R} 142 \mathrm{~b} ; \mathbf{\Delta}-\mathbf{\Delta}-\mathbf{\Delta}-\mathrm{R} 22 ; \bullet \bullet-\bullet-\mathrm{R} 32$; - - R404a; - - R407c; $\Delta-\boldsymbol{\Delta}-\boldsymbol{\Delta}-\mathrm{R} 410 \mathrm{a}$; $\bullet-\bullet-\mathrm{R} 507 \mathrm{a} ; \mathrm{x}-\mathrm{x}-\mathrm{x}-\mathrm{R} 401 \mathrm{a} ;$ ж-ж-ж-R502

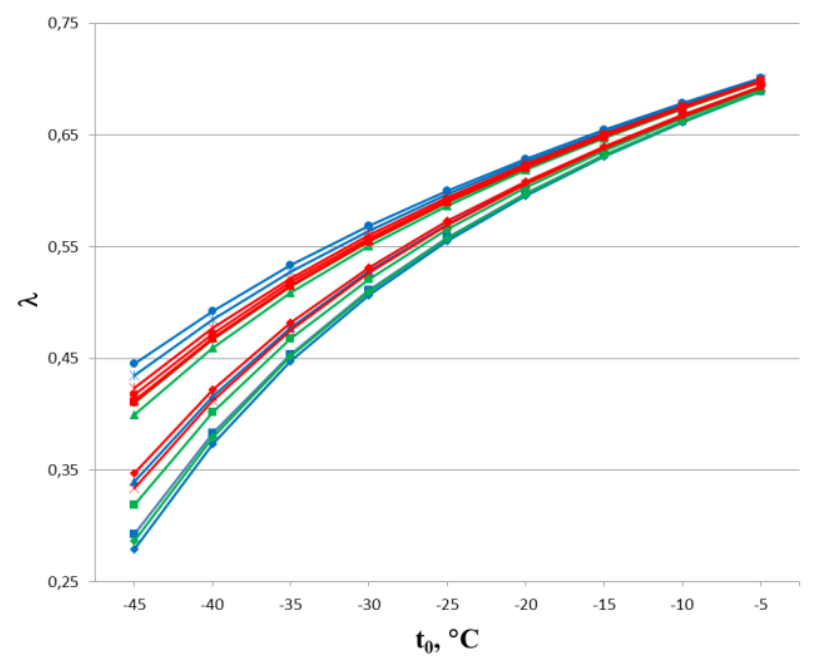

Рисунок 5 - Залежність коефіцієнта подачі компресора $\lambda$ від температури кипіння $t_{0}$ при температурі конденсаиії $t_{K}=25{ }^{\circ} \mathrm{C}$

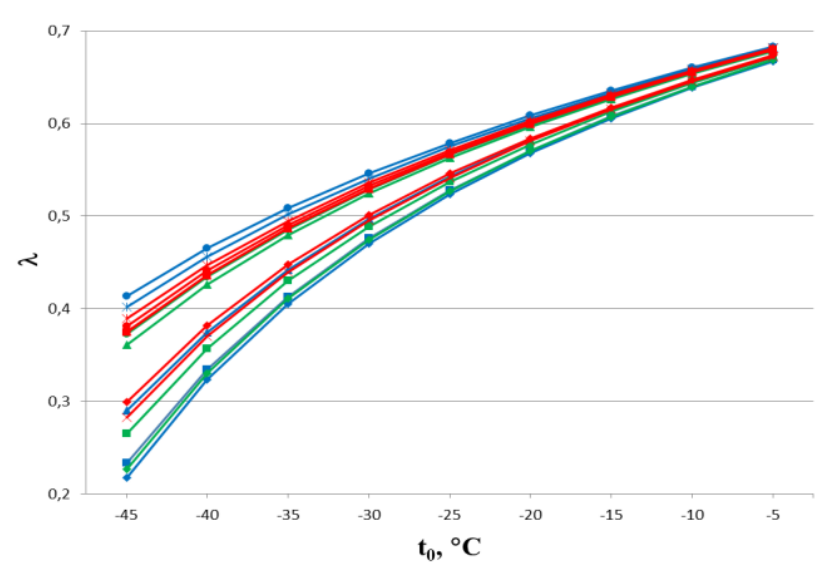

Рисунок 6 - Залежність коефіцієнта подачі компресора $\lambda$ від температури кипіння $t_{0}$ при температурі конденсації $t_{K}=30{ }^{\circ} \mathrm{C}$

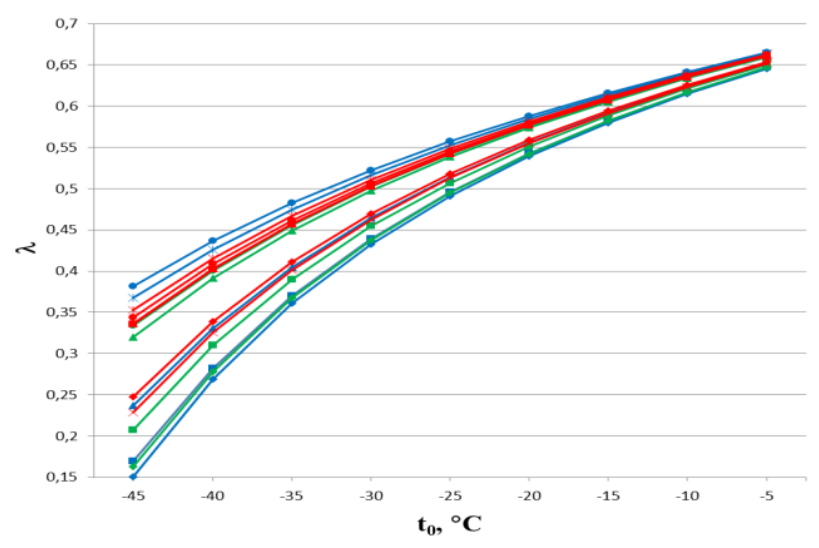

Рисунок 7 - Залежність коефіцієнта подачі компресора $\lambda$ від температури кипіння $t_{0}$ при температурі конденсації $t_{K}=35{ }^{\circ} \mathrm{C}$ 


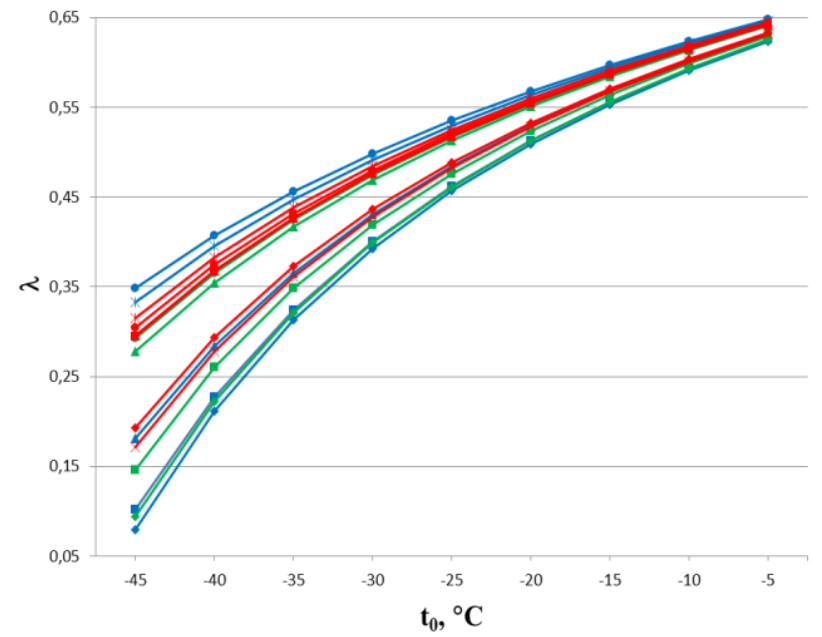

Рисунок 8 - Залежність коефіцієнта подачі компресора $\lambda$ від температури кипіння $t_{0}$ при температурі конденсації $t_{K}=40{ }^{\circ} \mathrm{C}$

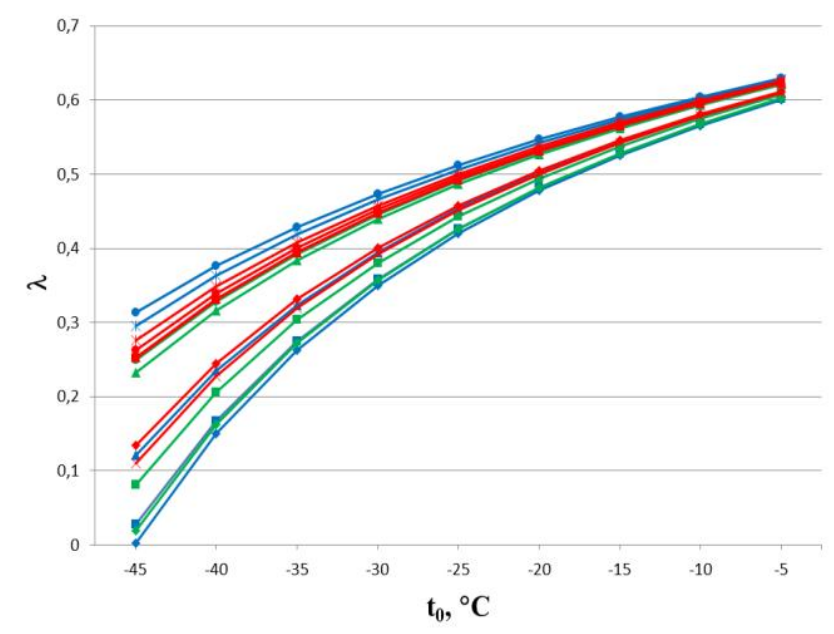

Рисунок 9 - Залежність коефіцієнта подачі компресора $\lambda$ від температури кипіння $t_{0}$ при температурі конденсаиії $t_{K}=45^{\circ} \mathrm{C}$

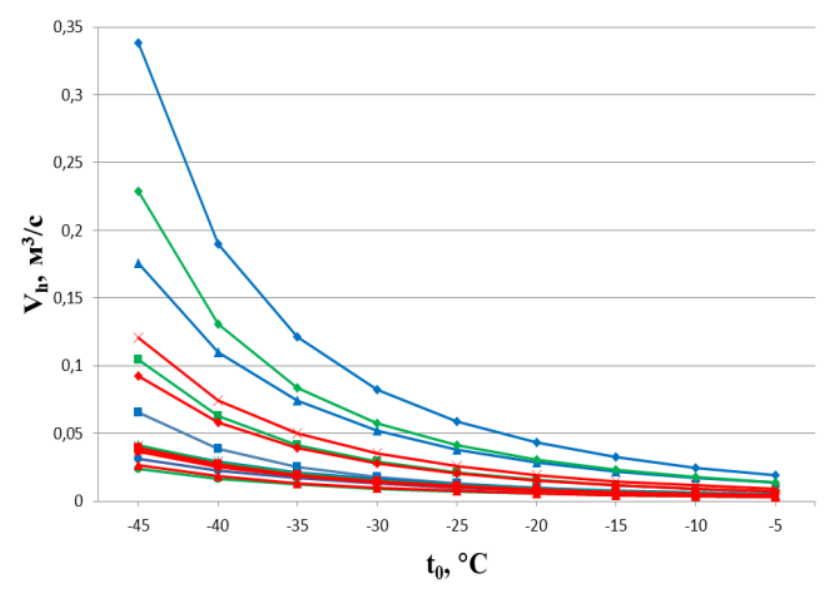

Рисунок 10 - Залежність теоретичного об' $є м y V_{h}$ від температури кипіння $t_{0}$ при температурі конденсаціі

$$
t_{K}=25^{\circ} \mathrm{C}
$$

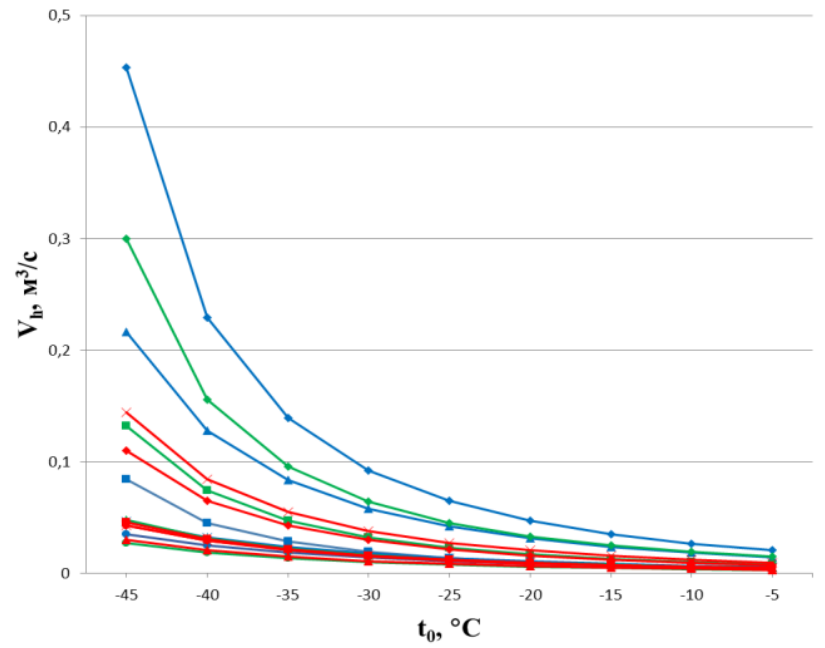

Рисунок 11 - Залежність теоретичного об'єму $V_{h}$ від температури кипіння $t_{0}$ при температурі конденсачіi $t_{K}=30{ }^{\circ} \mathrm{C}$

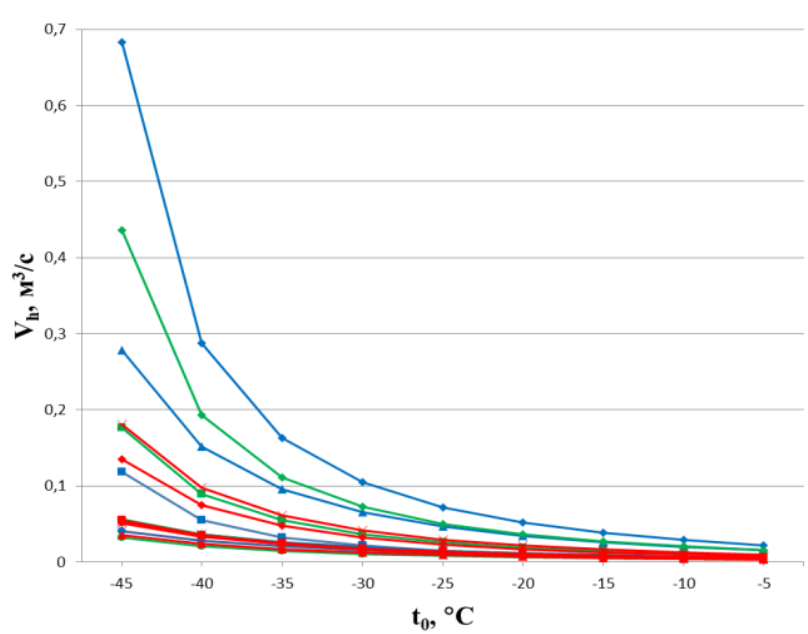

Рисунок 12 - Залежність теоретичного об'єму $V_{h}$ від температури кипіння $t_{0}$ при температурі конденсаціi $t_{K}=35^{\circ} \mathrm{C}$

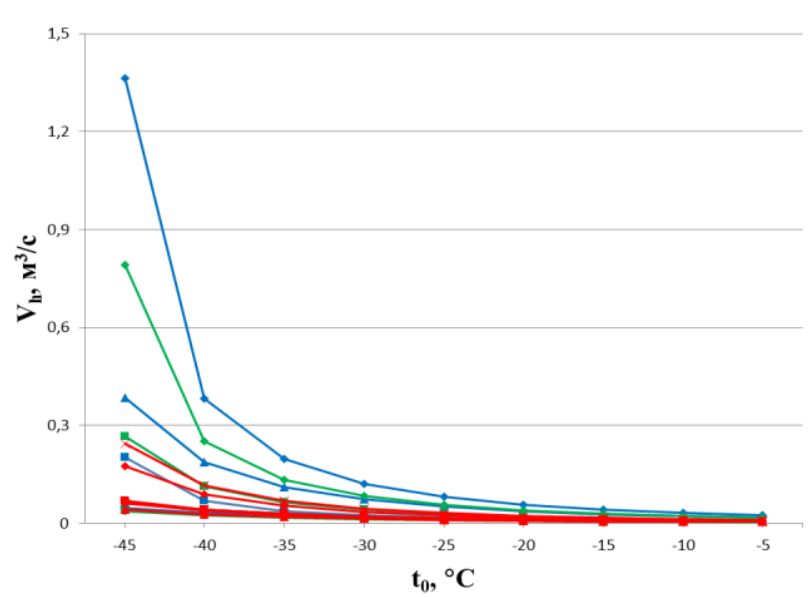

Рисунок 13 - Залежність теоретичного об' 'му $V_{h}$ від температури кипіння $t_{0}$ при температурі конденсації

$$
t_{K}=40{ }^{\circ} \mathrm{C}
$$




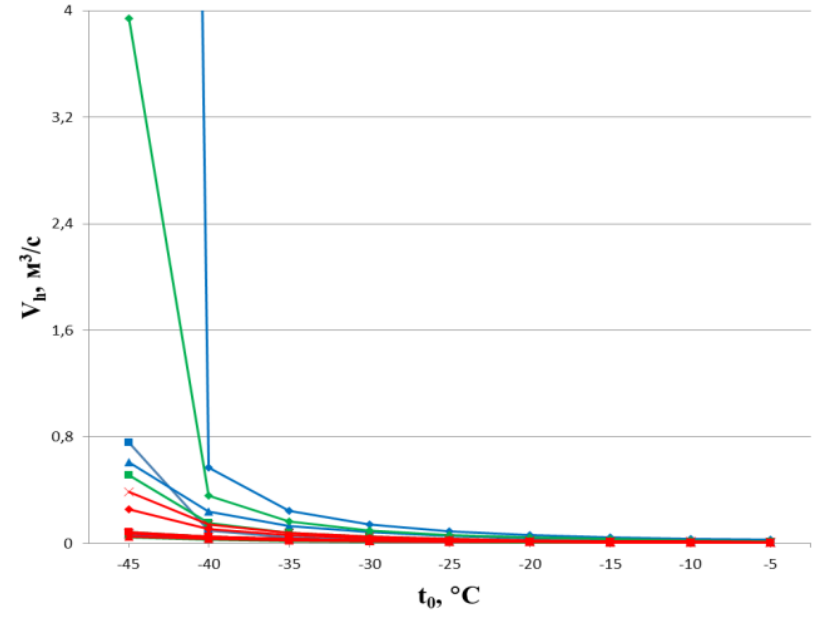

Рисунок 14 - Залежність теоретичного об'єму $V_{h}$ від температури кипіння $t_{0}$ при температурі конденсації

$$
t_{K}=45^{\circ} \mathrm{C}
$$

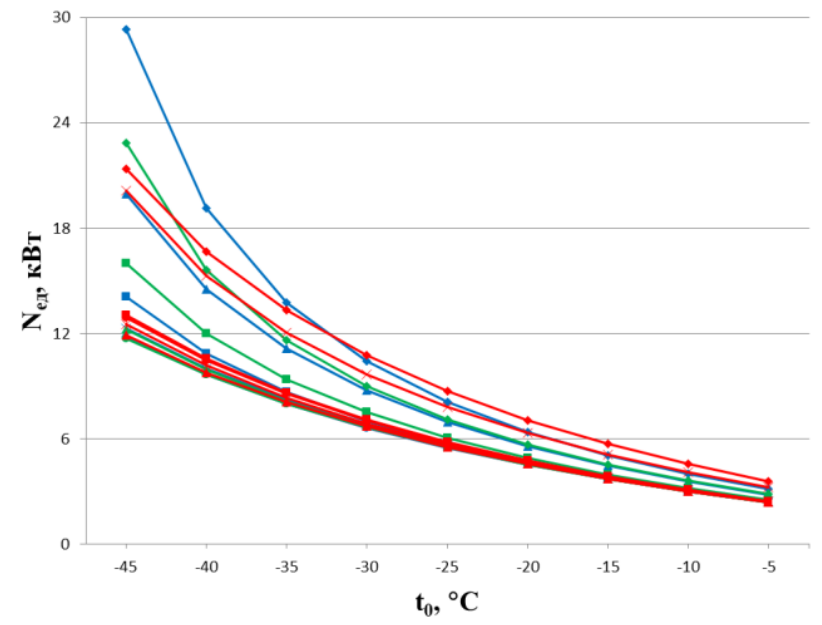

Рисунок 15 - Залежність потужності електродвигуна

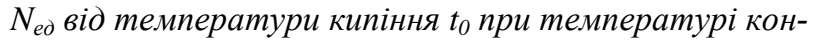
денсаиіï $t_{K}=25^{\circ} \mathrm{C}$

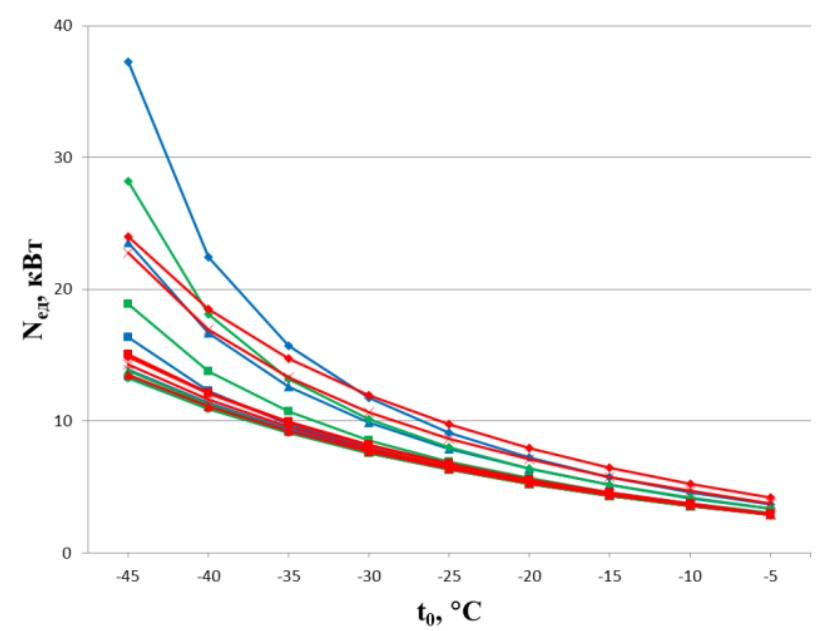

Рисунок 16 - Залежність потужності електродвигуна

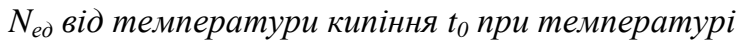

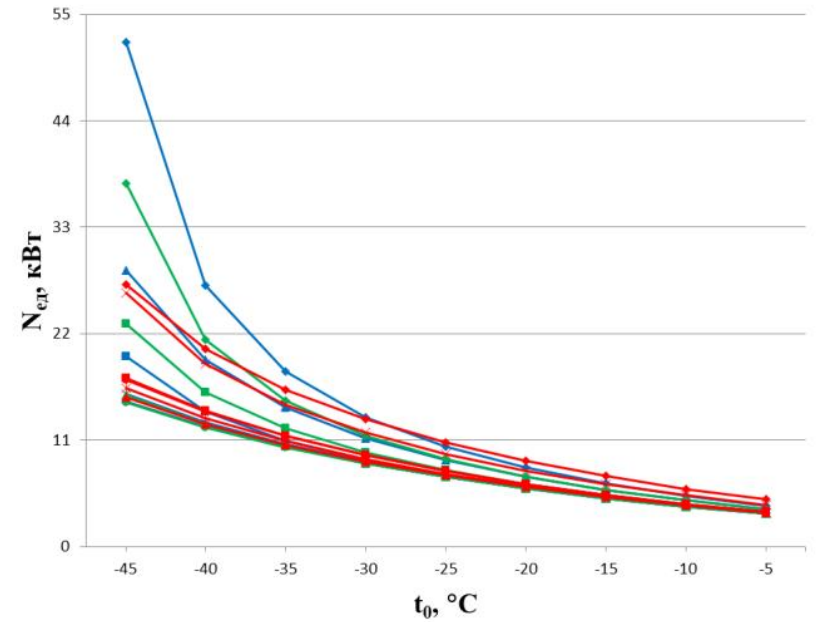

Рисунок 17 - Залежність потужності електродвигуна $N_{e д}$ від температури кипіння $t_{0}$ при температурі конденсаиї $t_{K}=35{ }^{\circ} \mathrm{C}$

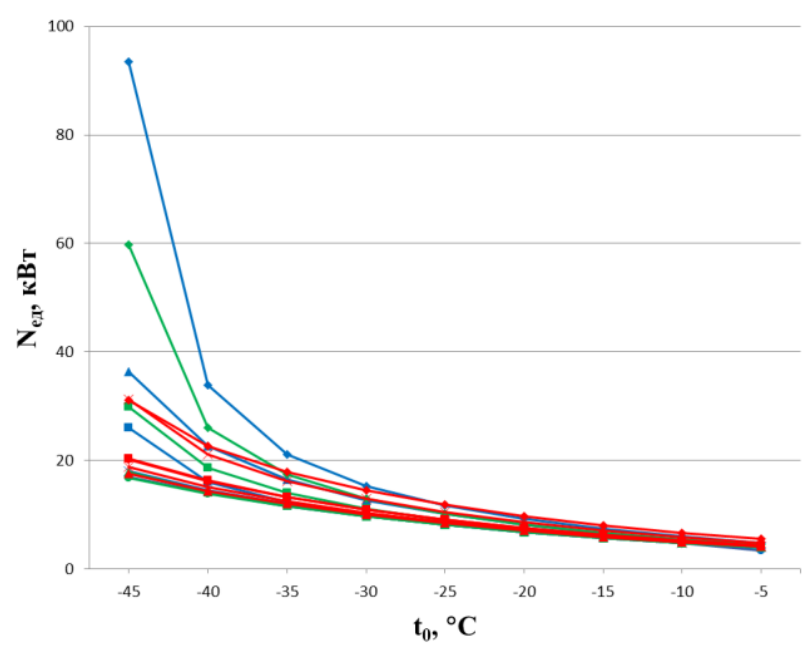

Рисунок 18 - Залежність потужності електродвигуна

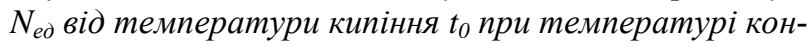
денсаиіï $t_{K}=40{ }^{\circ} \mathrm{C}$

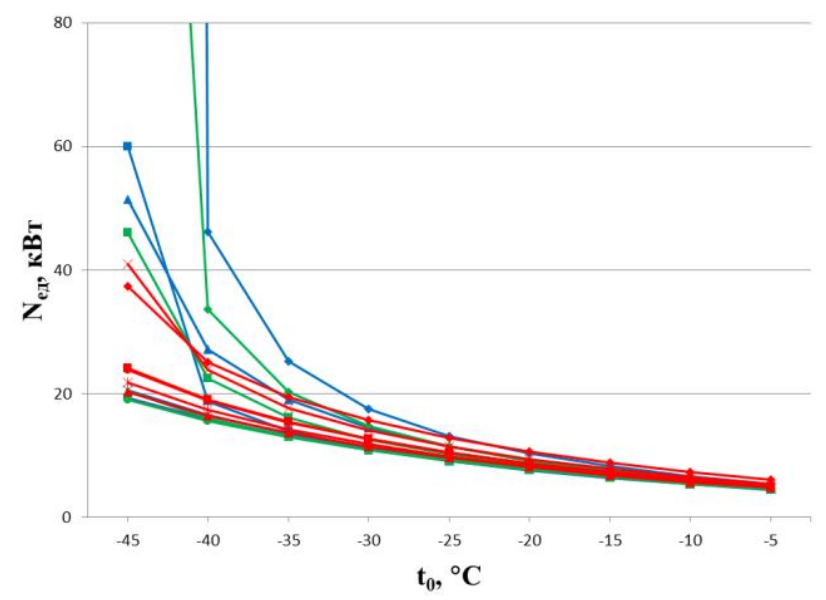

Рисунок 19 - Залежність потужності електродвигуна

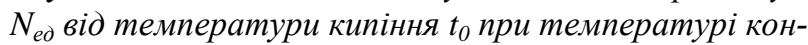
денсаиіiі $t_{K}=45^{\circ} \mathrm{C}$ 


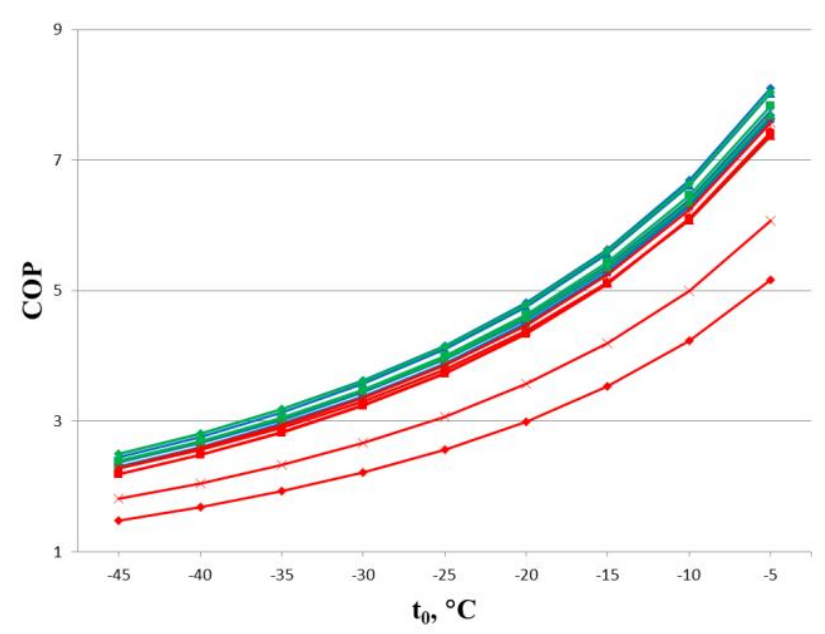

Рисунок 20 - Залежність холодильного коефіиіснта СОР від температури кипіння $t_{0}$ при температурі конденсаиії $t_{K}=25^{\circ} \mathrm{C}$

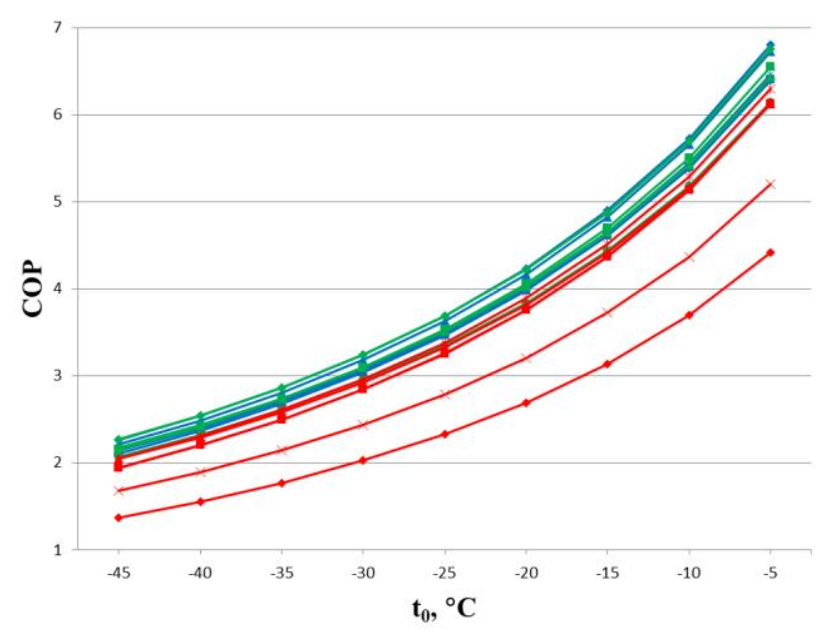

Рисунок 21 - Залежність холодильного коефіцієнта СОР від температури кипіння $t_{0}$ при температурі конденсаиіï $t_{K}=30^{\circ} \mathrm{C}$

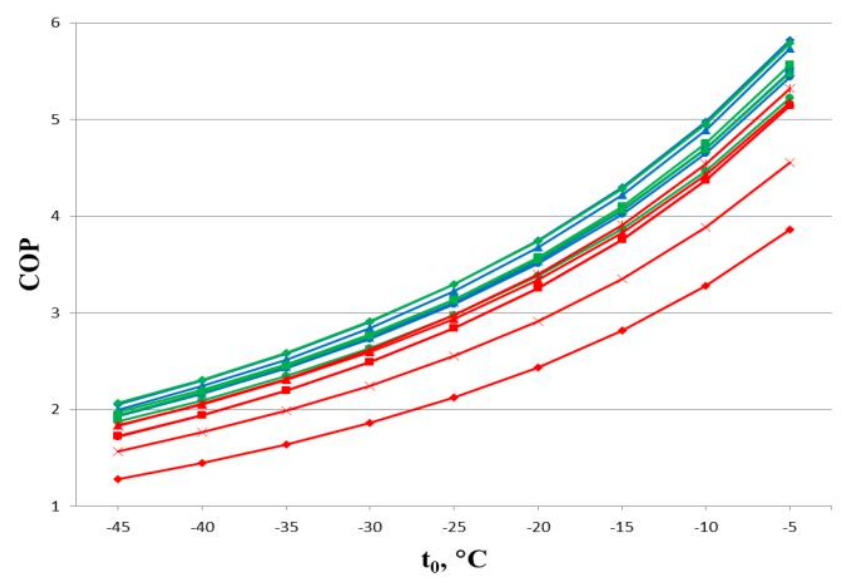

Рисунок 22 - Залежність холодильного коефіцієнта СОР від температури кипіння $t_{0}$ при температурі конденсаціiі $t_{K}=35^{\circ} \mathrm{C}$

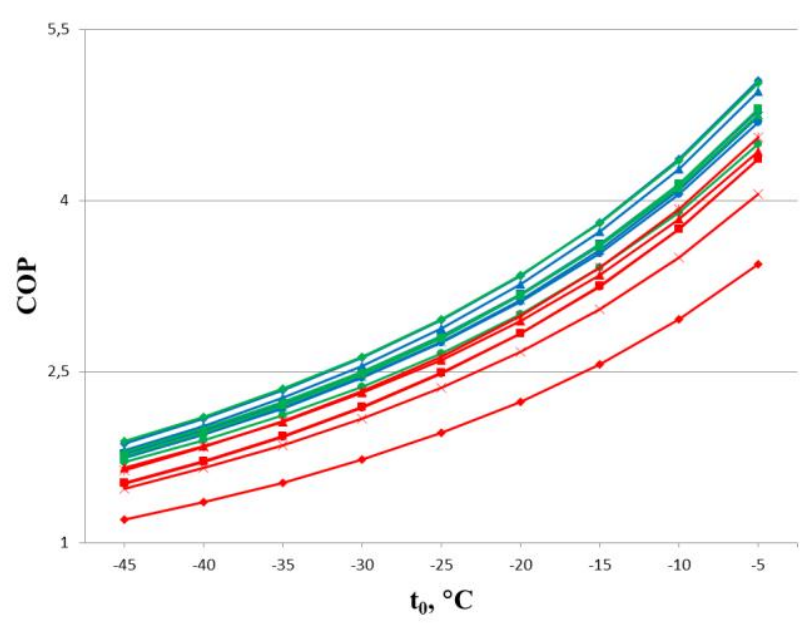

Рисунок 23 - Залежність холодильного коефіиієнта СОР від температури кипіння $t_{0}$ при температурі конденсаиї $t_{K}=40{ }^{\circ} \mathrm{C}$

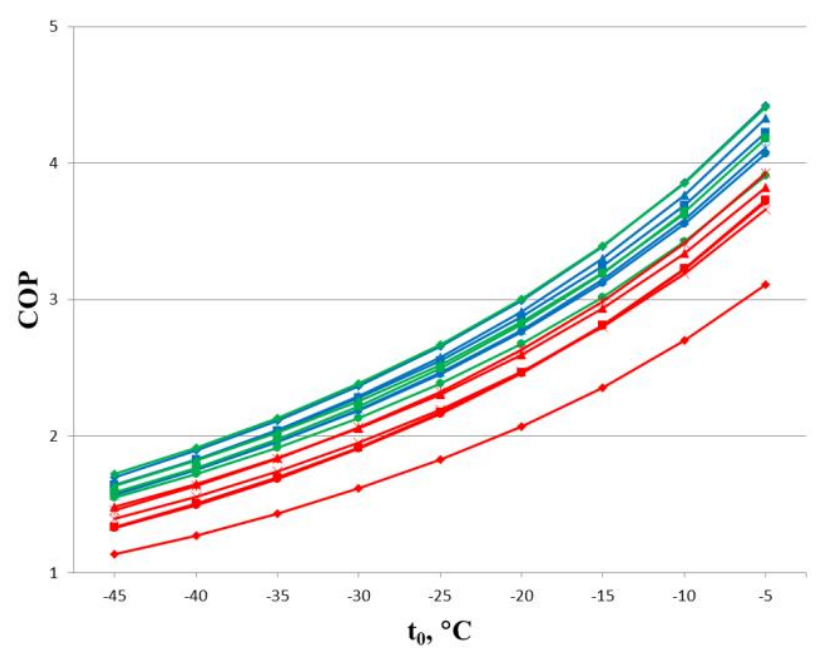

Рисунок 24 - Залежність холодильного коефіцієнта СОР від температури кипіння $t_{0}$ при температурі конденсаиї $t_{K}=45^{\circ} \mathrm{C}$

\section{3. Висновки}

На основі теоретичного аналізу роботи холодильної машини на досліджених холодоагентах можна зробити наступні головні висновки:

- альтернативні природні холодоагенти можуть скласти вагому конкуренцію однокомпонентним фреонам та фреонам-азеотропним сумішам не тільки завдяки обмеження застосування останніх через Монреальський і Кіотський протоколи, а і завдяки своїм термодинамічним властивостям і основним показникам роботи холодильної машини (висока питома холодопродуктивність, високий холодильний коефіцієнт, мала доза заправлення, низька температура кінця стискування, низька собівартість у порівнянні з дорогими фреонами);

- ізобутан $є$ якісною альтернативою фреонамазеотропним сумішам, які на сьогоднішній день повсюдно застосовуються у холодильній техніці, у холодильних машинах, що працюють на високих температурах кипіння $\left(t_{0}=-10 \ldots 0\right)$, що підтверджується досить широ- 
ким його використанням в якості холодоагенту у побутових холодильниках;

- пропан/пропілен є досить непоганою альтернативою фреонам-азеотропним сумішам у холодильних машинах, що працюють на низьких температурах кипіння;

- використання альтернативних природних холодоагентів у якості альтернативи існуючим потребує дуже високого рівня автоматизації холодильної машини через вибухонебезпечність цих речовин. Але для малих холодильних машин, де доза заправлення системи холодильним агентом не досить велика, використання альтернативних природних холодоагентів виглядає передвіщає досить привабливі перспективи.

\section{Література}

1. Бабакин, Б.С. Альтернативные хладагенты и сервис холодильных систем на их основе // Б.С. Бабакин, В.И. Стефанчук, Е.Е. Ковстунов / М: Колос, 2000. - 160 c.

2. Бабакин, Б.С. Хладагенты и холодильные масла // Б.С. Бабакин, С.Б. Бабакин / М.: ДеЛи плюс 2017 г. $390 \mathrm{c}$.

3. Бабакин, Б.С. Хладагенты, масла, сервис холодильных систем // Б.С. Бабакин, С.Б. Бабакин / Монография. - Рязань: Узорочье. -2003. - 470 с.

4. Маляренко, В.А. Енергетичні установки і довкілля // В. А. Маляренко, Г. Б. Варламов, Г. Н. Любчик та ін. / Харків: ХГАГХ, 2002.- 398 с.

\title{
Investigation of the characteristics of a refrigerating machine, working on natural alternative refrigerants
}

\author{
I. Podmazko, O. Podmazko \\ Odessa National Academy of Food Technologies, 112 Kanatnaia str., Odesa, 65039, Ukraine
}

\begin{abstract}
As the ozone crisis of the end of the last century has been overcome, at the moment the global warming of the Earth's at-mosphere is at the forefront and becomes the main ecological problem of the twenty-first century. In this connection, there was a significant pressure on the refrigeration and compressor equipment in order to significantly reduce greenhouse gas emissions. This is especially true of various hydrofluorocarbons (HFCs). As a result, the interest of experts and scientists is increasingly beginning to drag the possibility of widespread use in refrigeration and compressor technology of natural substances, which virtually no effect on the greenhouse effect of the atmosphere. These substances include ammonia, hy-drocarbons, carbon dioxide and some others. The development of refrigeration equipment is currently under the influence of three identified environmental problems of interconnected factors: a) the requirements of the Montreal Protocol on the Consumption of Substances that Deplete the Ozone Layer (primarily the Widespread R12 Coolant) and the temporary and quantitative restrictions on the use of transition group substances have a low ozone depleting potential (ODP); b) the requirements of the Kyoto Protocol to the United Nations Framework Convention on Climate Change on the regulation of greenhouse gas (GWP) emissions, which include the widely used refrigerant R134a and many other sub-stances used in refrigeration technics; c) a traditional requirement for increasing energy efficiency of all types of refrigeration equipment due to the growing competition on the domestic market and the provisions of certain laws "On Energy Efficiency" and the requirements of the standards for compulsory disclosure and informing consumers about the class of energy efficiency of refrigeration units. The purpose of the study is to compare and compare the characteristics of a refrigerating appliance, in which the refrigerants of HCFC and HFC groups, which are currently commonly used in the refrigeration industry, and the alternative natural refrigerants, which have not yet been widely used, act as a caustic agent. , but through the Kyoto and Montreal Protocols, is an essential alternative to the existing refrigerants of HCFC and HFC groups. The theoretical study of a single-foam refrigerating machine was carried out on 15 working substances (R717, R600, R600a, R290, R1270, R134a, R142b, R22, R32, R404a, R407c, R410a, R507a, R401a, R502)
\end{abstract}

Keywords: Refrigerating machine; ODP; GWP; Refrigerant.

\section{References}

1. Babakin B.S., Stefanchuk V.I., Kostunov E.E. (2000) Alternativnye hladagenty i servis holodilnyh sistem na ih osnove. Kolos, Moskow, 160 s. (in Russian)

2. Babakin B.S.. Babakin S.B. (2017) Hladagenty i holodilnye masla. DeLi plus, 390 s. (in Russian)
3. Babakin B.S.. Babakin S.B. (2003) Hladagenty, masla, servis holodilnyh system. Uzoroche, Ryazan, 470 s. (in Russian)

4. Maljarenko V.O., Varlamov G.B., Lubchik G.N. Energetichni ustanovki i dovkilly, KNAME, Kharkiv, 398 s. (in Ukrainian) 